\title{
THE IMPORTANCE OF INNOVATION IN DESIGNING A LUXURY TOURISM OFFERING: THE PERSPECTIVE OF TOURISM DESTINATION STAKEHOLDERS
}

\author{
Marta Cerović \\ Nadia Pavia \\ Tamara Floričić
}

https://doi.org/10.20867/tosee.05.23

\begin{abstract}
Purpose - The purpose of the paper is to examine the main components of luxury destination services and the preconditions needed for their designing. Because innovation represents the core part of a luxury tourism offering, its importance will be discussed from the destination management perspective

Methodology - The data were collected using the structured survey questionnaire method and the interview method on a sample of destination management stakeholders in the region of Istria. The structured questionnaire was used to quantify the presented statements. The interview method enabled respondents to support their viewpoints by providing opinions and attitudes referring to practical examples and experiences.

Findings - The concept of luxury tourism service is difficult to define because an understanding of the level of luxury depends on the user's perception of the service. Hence, the value of the research results is reflected in the qualification of the basic preconditions to designing a luxury tourism offering. The results of the research provide insight into the importance of innovation in creating a luxury tourism offering.

Contribution - A significant contribution of the paper is manifested in the systematisation and conceptualisation of the acknowledgments defining the innovative determinants of a luxury tourism offering. In addition to broadened the theoretical knowledge and enriching the scant body of scientific literature that deals with the topic mentioned above, this paper can be useful to destination stakeholders. It represents a starting point for further research into innovative luxury tourism services from the destination stakeholder perspective.
\end{abstract}

Keywords tourism offering, luxury tourism, luxury services, tourism destination, stakeholders, hospitality

\section{INTRODUCTION}

The rapidly changing, turbulent conditions on the tourism market are constantly posing new challenges in creating a tourism destination offering, thus making creativity and innovation essential preconditions to destination offering design. The shift of travel motivations from leisure to experiences has opened up entirely new opportunities in the offering of programmes and services in a destination, aimed at creating unforgettable experiences that guests cannot try at home and which they value more than the mere consumption of material goods. Additionally, the general upward trend in the standard of living is influencing ever greater demand and driving the qualitative development of 
ToSEE - Tourism in Southern and Eastern Europe, Vol. 5, pp. 177-189, 2019

M. Cerović, N. Pavia, T. Floričić: THE IMPORTANCE OF INNOVATION IN DESIGNING A

tourism services and facilities, resulting in accommodation facilities whose characteristics exceed the standards prescribed by law, making it difficult to express actual quality using the star rating system. Hence, such accommodation is valorised and positioned in the market as luxury accommodation. Because hospitality facilities are a component of a destination's tourism offering, an integrated tourism product needs to be designed that will incorporate luxury goods and services.

This paper aims to explore the opinions and attitudes of destination stakeholders concerning programmes and services that make up a luxury tourism offering, and the effect of innovativeness on designing such an offering. The purpose of this paper is manifested in the conclusions resulting from an analysis of obtained responses and in its contribution to the scant body of scientific literature dealing with the topic of a tourism destination's luxury offering.

\section{INNOVATIONS IN TOURISM}

One of the most complex activities of today's modern society, tourism is a dynamic system involving numerous commercial and non-commercial activities that together form a tourism offering. Changes in tourism trends as well as increasingly discerning tourism demand are driving the need for tourism offering innovation. Dzhandhugazova et al. (2016) argue that one of the core trends in this sphere is the development and application of a variety of innovations and new elements that can serve as a powerful impetus for the development of tourism. Tourism offering innovation "introduces something new into the way of life, organization, timing and placement of what can generally be described as the individual and collective processes that relate to consumers" (Barcet, 2010). Tourism offering innovation depends on creativity and refers to new ideas and new approaches to designing an offering and developing novel forms of special-interest tourism. A luxury tourism offering is the basis for developing luxury tourism that offers unique, personalised services. One of the distinctive features of luxury tourism is the fact that it is a complete opposition to mass tourism (WTF, 2019)

The tourists of today differ from those of previous generations; they expect tourism services to provide quality as well as experiences. Hence, tourism destinations are under pressure to create and offer original and innovative products that will set them apart from other destinations. Innovation is not about finding new ways of doing business; it is about finding new ways to survive in the market (Mrnjavac, Pavia, \& Maršanić, 2018). Innovation and new service development are important strategic features to assure growth and sustainable wealth for every industry, but in particular for those industries where markets are saturated and clients choose products and services from all over the world, such as is the case in tourism (Peters \& Pikkemaat, 2006). De Brentani (2001) refers to innovation as the designing of new products, services or processes. Schumpeter (1934) distinguishes between five areas in which entrepreneurs can apply innovativeness: creating new products or services, new production processes, new markets, new suppliers, and changing organization or management systems. 
ToSEE - Tourism in Southern and Eastern Europe, Vol. 5, pp. 177-189, 2019

M. Cerović, N. Pavia, T. Floričić: THE IMPORTANCE OF INNOVATION IN DESIGNING A

Innovations in tourism represent the introduction of a new or improved component which intends to bring tangible and intangible benefits to tourism stakeholders and the local community, improve the value of the tourism experience and the core competencies of the tourism sector and hence enhance tourism competitiveness and /or sustainability. Innovation in tourism may cover potential areas, such as tourism destinations, tourism products, technology, processes, organizations and business models, skills, architecture, services, tools and/or practices for management, marketing, communication, operation, quality assurance and pricing (UNWTO, 2016).

Tourism offering innovation, which involves all stakeholders, can prevent destructive and chaotic development and help to create a framework for integrated destination management. Innovations to the tourism offering in the form of new products and services can become a major factor of the tourist experience and a reason to travel to a specific tourism destination. Pavia \& Floričić (2017) point out that new, unique and personalised services and facilities, capable of providing a specific experience and high level of satisfaction, will undoubtedly ensure repeat visits of tourists to a destination.

Innovation in tourism is multifaceted and can involve (Tounta, 2015):

- $\quad$ product innovation with new products and services

- $\quad$ process innovation with new ways of delivering tourism services

- logistic innovation with new ways of supplying products or services to customers and

- market innovation focusing on new ways of marketing and on consumer behaviour.

A trend in tourism is the emergence of a new luxury consumer, seeking value, uniqueness and personal experiences. In designing a luxury tourism offering, all offering stakeholders are focused on providing new personalised experiences and unforgettable moments through an offering that is authentic, impressive, unique and exclusive.

In tourist destinations, social and sustainable innovations also require new planning, management and organisational structures, more embracive of local resources, local community's collective interests and quality of life and involving practices oriented towards forms of sustainable development (Brandão, 2014). All tourism destination stakeholders participate in designing new, innovative tourism offerings. Innovations in tourism refer to transformations that fall into the following impact categories (Hjalager, 2015):

1. Changing the properties and varieties of the goods and services as they are experienced by the tourists

2. Increasing the social and physical efficacy, for example, the power for the tourists to produce the benefits for themselves

3. Increasing the productivity and efficacy in tourism enterprises and restructuring the input factors such as energy, labour, capital, and land

4. Forming new destinations

5. Enhancing mobility to and within destinations

6. Altering the way of passing information within and across organizational boundaries

7. Changing the institutional logic and the power relations. 
ToSEE - Tourism in Southern and Eastern Europe, Vol. 5, pp. 177-189, 2019

M. Cerović, N. Pavia, T. Floričić: THE IMPORTANCE OF INNOVATION IN DESIGNING A

Smits (2002) describes innovation as a successful combination of hardware, software and orgware viewed from a societal and/or economic point of view. This means that an innovative tourism offering includes not only luxury products and services, but also the knowledge and skills of the people offering such products/services, together with the organisational conditions required for their realisation. In synergy with new forms of the tourism offering, an innovative accommodation offering can help to increase competitiveness (Floričić \& Pavia, 2018). Maráková \& Medved’ová (2016) state that management in tourism destinations finds it difficult to ensure leadership and coordination. In order to ensure effective co-ordination, it is necessary to innovate and develop an integrated approach, which should include all stakeholders in the decisionmaking process.

\section{LUXURY SERVICES IN TOURISM}

The level of luxury of tourism services is difficult to define because understanding luxury depends on the perspective of tourists; individual perceptions of luxury in general, and in particular of luxury tourism, vary greatly (Stankova \& Kaleichev, 2013). In addition to the concept of luxury being highly subjective (Wiedmann, Hennigs, \& Siebels, 2009) the meaning of luxury also differs from one person to another (Monkhouse, Barnes, \& Stephan, 2012). Accordingly, despite the importance of the luxury market, there is no one definition of luxury tourism and there is also a lack of one common definition for luxury travel (Stankova \& Kaleichev, 2013).

Luxury tourism or high-life tourism includes all categories of clients for which practicing tourism is not conditioned by the level of their earnings, in the sense that money is not an issue for them since they have more than enough (Popescu \& Olteanu, 2014). Luxury tourism is characterised by a personalised, premium offering that attracts consumers with the particular way services are rendered. A luxury offering is differentiated, unique and exclusive. Although it is a product or service that can be offered to everyone, not everyone can afford it. It is difficult to define what tourists see as superior, convenient and engaging. European luxury travellers are generally looking for such things as (CBI, 2014): personalised service, preferably one on one; good-quality beds with good-quality bed linen; reliable transport; comfortable seats when travelling, with plenty of legroom; good-quality food and wine; exclusivity; positive and professional interaction with staff. Stakeholders in a destination are often faced with a situation in which a luxury offering is not defined by exceptional quality alone, that is, quality is no longer enough to differentiate products (Gilmore \& Pine, 2002), so that innovation to create high-quality experiences is more important than goods or service innovation (Pine \& Gilmore, 2014).

Because experiences represent a vital component in satisfying the need for enjoying luxury goods and service, many authors include this criterion in their definition of luxury. Tynan et al. (2010) define luxury products as high quality, expensive and non-essential products and services that appear to be rare, exclusive, prestigious and authentic and offer high levels of symbolic and emotional/hedonic values through customer experiences. 
ToSEE - Tourism in Southern and Eastern Europe, Vol. 5, pp. 177-189, 2019

M. Cerović, N. Pavia, T. Floričić: THE IMPORTANCE OF INNOVATION IN DESIGNING A

According to Bakker (2005), four major elements evoke a sense of luxury: uniqueness, prestige / social status, cost and time. A unique tourism offering is able to create a sense of luxury, as the tourist knows that the product is not in the reach of everybody and this helps tourists to express their intrinsic values (Chan, To, Chu, \& Zhang, 2014). Exclusive services, facilities and experiences that are unique can evoke a sense of luxury. It is believed that tourists perceive an offering as a luxury when it gives them a certain prestige, such as staying in an exclusive destination with personalised service. When the price of a premium tourism offering is high, it is considered to be a luxury, especially if the offering has no tangible quality. Luxury services can be explained as those whose ratio of functional utility to price is low while the ratio of intangible and situational utility to price is high (Nueno \& Quelch, 1998). Luxury does not imply only pleasure but also convenience with regard to others; it is a privilege experienced by few and to the tourist it means the right balance of local insight, independence and flexibility (A Luxury Travel Blog, 2013). According to Yang and Matilla (2016) luxury services in tourism possess functional, hedonic and symbolic (expressive) values, while Vigneron and Johnson (2004) provide a broader concept stating that a luxury product contains five basic elements: exceptional quality; hedonic value; conspicuousness; unique, rare or exclusive product; and social value.

The components of a luxury tourism offering are concurrently tangible and emotional and enable guests to realise their intrinsic motivations and values though luxury tourism products. Luxury tourism services exceed the boundary of satisfying the basic travel needs (luxury accommodation and food/drinks) and are tightly linked to experiences not affordable to the masses, experiences that when consumed can satisfy the highest levels of human needs - self-actualisation and social status. Accordingly, a luxury tourism offering implies added value for guests, carefully designed programmes and services that are not focused exclusively on spending leisure time but also represent value that money cannot buy (affective value is greater than material value), that is, an authentic experience of staying in a destination.

\section{RESEARCH METHOD}

A survey of stakeholder attitudes was conducted in November 2018 in Pula. The sample encompassed different stakeholder groups in southern Istria. A total of 26 respondents were grouped into 7 categories: local self-government units -3 respondents $(11.5 \%)$; DMOs and tourist boards -3 respondents (11.5\%); educational institutions -2 respondents $(7.7 \%)$; accommodation offering stakeholders -11 respondents $(42.3 \%)$; DMCs, tour operators -3 respondents $(11.5 \%)$; students -2 respondents $(7.7 \%)$; and other stakeholders - 2 respondents $(7.7 \%)$. The representatives of stakeholder organisations are people in managerial positions, and the students are studying tourism and have work experience in seasonal jobs in tourism. Both the sample competency level and the research validity level were assessed as high. The work experience of respondents was identified as a crucial factor in understanding issues, considering that work experience enables deeper insight and a broader perspective in problem comprehension and in identifying which innovative service mix in the destination defines the luxury tourism offering. Research was conducted using a combination of structured questionnaire and the interview method. The questionnaire was designed in four parts. 
ToSEE - Tourism in Southern and Eastern Europe, Vol. 5, pp. 177-189, 2019

M. Cerović, N. Pavia, T. Floričić: THE IMPORTANCE OF INNOVATION IN DESIGNING A ...

The first part explored the above-mentioned structure and experience of respondents. The second part asked respondents to use a 5-point Likert scale to rate the intensity of influence regarding statements that refer to the importance of the overall destination experience and effect on the experience of luxury. The third part also used a Likert scale to investigate the level of agreement of respondents with the effect of luxury tourism and hospitality development on various aspects of the tourism system which contribute to evoking special experiences through complementarity. Finally, the fourth part of the study was designed to examine the development potentials and valorisation of luxury tourism, based on interviews with respondents.

\section{RESULT AND DISCUSSION}

An evaluation of the sample of respondents reveals that 6 respondents $(23.1 \%)$ have up to 3 years of work experience, 5 respondents $(19.2 \%)$ have 3 to 7 years of experience, 2 respondents (7.7\%) have 7 to 10 years, and 13 respondents $(50 \%)$ have more than 10 years of work and experience in tourism and hospitality

\section{Tables 1: Attitudes of tourism destination stakeholders}

\begin{tabular}{|c|c|c|c|c|c|c|c|c|c|}
\hline $\begin{array}{l}\text { STATEMENT - } \\
\text { INTENSITY }\end{array}$ & & 1 & 2 & 3 & 4 & 5 & $\Sigma$ & Ave. & Rank \\
\hline \multirow{2}{*}{$\begin{array}{l}\text { Perception of luxury } \\
\text { through products }\end{array}$} & $\mathbf{N}$ & 2 & 0 & 5 & 12 & 7 & 26 & 3.70 & 4 \\
\hline & $\%$ & 7.7 & 0.0 & 19.2 & 46.2 & 26.9 & 100 & & \\
\hline \multirow{2}{*}{$\begin{array}{l}\text { Perception of luxury } \\
\text { through the tourist } \\
\text { experience }\end{array}$} & $\mathbf{N}$ & 0 & 1 & 2 & 8 & 15 & 26 & 4.26 & 3 \\
\hline & $\%$ & 0 & 3.8 & 7.7 & 30.8 & 57.7 & 100 & & \\
\hline \multirow{2}{*}{$\begin{array}{l}\text { Perception of luxury } \\
\text { through an innovative } \\
\text { accommodation offering }\end{array}$} & $\mathbf{N}$ & 0 & 0 & 2 & 7 & 17 & 26 & 4.41 & 1 \\
\hline & $\%$ & 0.0 & 0.0 & 7.7 & 26.9 & 65.4 & 100 & & \\
\hline \multirow{2}{*}{$\begin{array}{l}\text { Perception of luxury } \\
\text { through innovative } \\
\text { services/facilities in the } \\
\text { destination }\end{array}$} & $\mathbf{N}$ & 0 & 0 & 4 & 5 & 17 & 26 & 4.33 & 2 \\
\hline & $\%$ & 0.0 & 0.0 & 15.4 & 19.2 & 65.4 & 100 & & \\
\hline $\begin{array}{l}\text { STATEMENT - } \\
\text { AGREEMENT } \\
\end{array}$ & & 1 & 2 & 3 & 4 & 5 & $\Sigma$ & Ave. & Rank \\
\hline \multirow{2}{*}{$\begin{array}{l}\text { Image building through } \\
\text { special tourist } \\
\text { experiences }\end{array}$} & $\mathbf{N}$ & 0 & 0 & 0 & 4 & 22 & 26 & 4.67 & 1 \\
\hline & $\%$ & 0.0 & 0.0 & 0.0 & 15.4 & 84.6 & 100 & & \\
\hline \multirow{2}{*}{$\begin{array}{l}\text { The influence of the } \\
\text { accommodation offering } \\
\text { on perceived destination } \\
\text { luxury }\end{array}$} & $\mathbf{N}$ & 3 & 2 & 9 & 7 & 5 & 26 & 3.22 & 6 \\
\hline & $\%$ & 11.5 & 7.7 & 34.6 & 26.9 & 19.2 & 100 & & \\
\hline \multirow{2}{*}{$\begin{array}{l}\text { The influence of the } \\
\text { destination offering on } \\
\text { perceived destination } \\
\text { luxury }\end{array}$} & $\mathbf{N}$ & 0 & 0 & 4 & 7 & 15 & 26 & 4.26 & 3 \\
\hline & $\%$ & 0.0 & 0.0 & 15.4 & 26.9 & 57.7 & 100 & & \\
\hline \multirow{2}{*}{$\begin{array}{l}\text { Compatibility of the } \\
\text { luxury offering with } \\
\text { sustainable development }\end{array}$} & $\mathbf{N}$ & 0 & 1 & 11 & 7 & 7 & 26 & 3.63 & 4 \\
\hline & $\%$ & 0.0 & 3.8 & 42.3 & 26.9 & 26.9 & 100 & & \\
\hline
\end{tabular}


ToSEE - Tourism in Southern and Eastern Europe, Vol. 5, pp. 177-189, 2019

M. Cerović, N. Pavia, T. Floričić: THE IMPORTANCE OF INNOVATION IN DESIGNING A ...

\begin{tabular}{|l|r|r|r|r|r|r|r|r|c|}
\hline STATEMENT - & & $\mathbf{1}$ & $\mathbf{2}$ & $\mathbf{3}$ & $\mathbf{4}$ & $\mathbf{5}$ & $\mathbf{\Sigma}$ & Ave. & Rank \\
\hline AGREEMENT & $\mathbf{N}$ & 2 & 2 & 4 & 11 & 7 & 26 & 3.59 & 5 \\
\hline $\begin{array}{l}\text { The potential of a luxury } \\
\text { accommodation offering } \\
\text { in rural development }\end{array}$ & $\mathbf{\%}$ & 7.7 & 7.7 & 15.4 & 42.3 & 26.9 & 100 & & \\
\hline $\begin{array}{l}\text { The effect of luxury } \\
\text { tourism on demand in } \\
\text { traditional markets }\end{array}$ & $\mathbf{N}$ & 7 & 7 & 5 & 4 & 3 & 26 & 2.48 & 8 \\
\cline { 2 - 11 } & $\mathbf{\%}$ & 26.9 & 26.9 & 19.2 & 15.4 & 11.5 & 100 & & \\
\hline $\begin{array}{l}\text { Stakeholder awareness } \\
\text { regarding the needs of } \\
\text { luxury guests }\end{array}$ & $\mathbf{N}$ & 5 & 3 & 11 & 4 & 3 & 26 & 2.78 & 7 \\
\cline { 2 - 11 } $\begin{array}{l}\text { The need for a luxury } \\
\text { tourism development } \\
\text { strategy }\end{array}$ & $\mathbf{N}$ & 19.2 & 11.5 & 42.3 & 15.4 & 11.5 & 100 & & \\
\cline { 2 - 10 } & $\mathbf{\%}$ & 0.0 & 0.0 & 0.0 & 19.2 & 80.8 & 0.0 & & \\
\hline
\end{tabular}

Source: Author's research

Further to obtained research results, summarised data are presented for the assessment by stakeholders of the intensity of influence with regard to the investigated attitudes. The first statement examines the extent to which products affect the experience of luxury in tourism. Results indicate a high level of influence $(73.1 \%$ ), with only $7.7 \%$ of respondents judging that the price and characteristics of products are not important. Respondents reported an even higher intensity of influence when evaluating the importance of experiences in tourism on the perception of luxury (88.5\%), innovativeness in organising accommodation services/facilities $(92.3 \%)$ and designing special programmes and services $(84.6 \%)$ in accommodation facilities and in the tourism destination, the services and facilities of which should support a strategy of synergistic development.

Further evaluation of different aspects influencing the development of a luxury tourism offering focuses on the level of agreement with statements that explore the potentials of luxury tourism development. The entire group of respondents agreed with the statement concerning the contribution of special tourist experiences in building a destination's image; fully $84.6 \%$ of respondents strongly agreed with this statement. With regard to the statement that luxury accommodation facilities define a destination's luxury offering, $19.2 \%$ of respondents did not agree with the statement, $34.6 \%$ were indifferent, and $46.2 \%$ considered that advances in quality improvement and destination repositioning cannot be made without luxury accommodation facilities. Support to this was given through the implementation of innovation through a variety of physical content (destination hardware) and service programmes (software) recognised in luxury accommodation offerings $(84.6 \%$ of respondents agree). Considering sustainability in the context of a luxury accommodation and destination offering, 53.8\% of respondents recognised the importance of coordinated, responsible development; $3.8 \%$ were of the opposite opinion; and $42.3 \%$ were indifferent. With tourists becoming increasingly aware of the importance of sustainable development and social responsibility, products and services with sustainability certifications help to enhance competitiveness in the sphere of luxury tourism. 
ToSEE - Tourism in Southern and Eastern Europe, Vol. 5, pp. 177-189, 2019

M. Cerović, N. Pavia, T. Floričić: THE IMPORTANCE OF INNOVATION IN DESIGNING A

In considering the effect of luxury offering development on the development of rural areas, $69.9 \%$ of respondents appreciate the importance and potential of rural regeneration through luxury tourism. Rural areas have the potential for designing innovative facilities and services connected with back-to-roots tourism, pristine nature and authenticity, as confirmed by qualitative results further in the study. The disagreement of $15.4 \%$ of respondents is explained by the understanding and recognition of the shortcomings in the quality of the offering of additional services and facilities in rural regions, which represents an area for offering innovation.

The evaluation of attitudes regarding the threat of losing established positions on traditional outbound markets shows that $26.9 \%$ of respondents think that market positions will be lost and have doubts about the successful performance of new offerings, $19.2 \%$ are indifferent, and most $(53.8 \%)$ believe that market positions will not be lost. It stands to reason that the transformation of the existing accommodation and destination offerings into luxury offerings would affect guest segmentation.

To introduce the last part of the study focused on the qualitative examination of stakeholder attitudes regarding luxury products that help differentiate the offering and represent an improvement in quality, a question was posed concerning the extent to which destination stakeholders are capable of identifying the actual needs and wants of guests using luxury tourism services. Only $26.9 \%$ of respondents stated they are familiar with the requirements of and trends in luxury tourism demand, $42.3 \%$ have no clear opinion regarding the matter, while $30.8 \%$ considered there is room for education, for identifying and evaluating the actual needs and wants of luxury tourists which currently have not been developed to any significant level. In the final question, all respondents $(100 \%)$ concluded that ensuring luxury tourism development in the destination requires putting in place a special strategy, encouraging in-depth thinking and an understanding of all aspects of and influences on the environment, the local community in particular, and ensuring a sustainable approach to a new evaluation of the destination's natural and cultural resource bases as well as the involvement of all stakeholders, aimed at responsible, synergistic management.

The next section examines the attitudes of destination stakeholders regarding key elements that reinforce the perception of luxury. The authors questioned the stakeholders concerning the predominance of either innovative luxury accommodation facilities in the destination or innovative destination programmes and services. Using the Chi squared test, statement results were compared with expected values. Statistical indicators are presented in Table 2. 
ToSEE - Tourism in Southern and Eastern Europe, Vol. 5, pp. 177-189, 2019

M. Cerović, N. Pavia, T. Floričić: THE IMPORTANCE OF INNOVATION IN DESIGNING A ...

Tables 2: Destination stakeholders' attitudes - perception of luxury and innovative aspects

\begin{tabular}{|l|c|c|c|}
\hline & $\begin{array}{c}\text { Luxury } \\
\text { Accommodation -\% }\end{array}$ & $\begin{array}{c}\text { Luxury programmes } \\
\text { and services - \% }\end{array}$ & $\begin{array}{c}\text { Marginal Row } \\
\text { Totals }\end{array}$ \\
\hline Obtained frequency & 46.2 & 84.7 & 130.9 \\
\hline Expected frequency & 50.0 & 50.0 & 100.0 \\
\hline $\begin{array}{l}\text { Marginal Column } \\
\text { Totals }\end{array}$ & 96.2 & 134.7 & 230.9 \\
\hline $\begin{array}{l}\text { Chi-squared test: } \\
24.371\end{array}$ & p-value: 7.9e-7 & $\begin{array}{l}\text { Yates, p-value: } \\
0.00000118\end{array}$ & $\begin{array}{l}\text { Yates X2 test: } \\
23.611\end{array}$ \\
\hline
\end{tabular}

Source: Author's research

Results presented in Table 2 indicate that relative to the expected frequency, when perceiving luxury respondents place greater value on luxury programmes and services than on luxury accommodation. Luxury is not perceived only through an accommodation facility (reported by $46.2 \%$ of respondents, relative to the expected $50 \%$ ); the perception of luxury is also affected by luxury programmes and services. According to the perception of stakeholders, this involves enriching the existing offerings with luxury services, ranging from transportation in the destination, excursion offerings, and shopping to gastronomic, artistic and educational services and facilities designed within the context of a luxury cultural-tourism offering.

The value of the $\mathrm{X}^{2}$ test for expectations is 24.371 , confirming the total share of respondents $(87.7 \%)$ who recognised the importance of luxury programmes and services, relative to the expected value of $50 \%$. The result points to the importance of the coordinated development of all destination facilities and services together with accommodation facilities and to the synergistic effects of complementarity of the quality and identity of the destination's overall offering.

The final part of the survey involved interviews with stakeholders, asking them to express their attitudes concerning the designing of a luxury tourism offering and the special features and potential it involves. A summarisation of attitudes points to the conclusion that a luxury tourism offering is the result of the integration of all stakeholders in offering innovation and design. Destination stakeholders agree that a luxury offering can drive the pre-season and post-season by providing new exclusive facilities and services and through investment in existing services. This can be further strengthened by the design of special products that combine authenticity and modern trends and technology. Respondents see luxury tourism as a medium that can be used to promote innovative products, such as luxury gamification, gourmet services and facilities, innovative accommodation structures and all other products created through the collaboration of local stakeholders. They also hold the view that the potential of storytelling as a driver of luxury accommodation in Croatia is completely untapped and that considerable advancements are needed in that segment given the emotional bond that storytelling can create between guests and a destination. The precondition to storytelling - that is, the sharing of meaningful stories about experiences in a destination - can be created by organising an offering in which guests personally participate and 
ToSEE - Tourism in Southern and Eastern Europe, Vol. 5, pp. 177-189, 2019

M. Cerović, N. Pavia, T. Floričić: THE IMPORTANCE OF INNOVATION IN DESIGNING A

which incorporates traditional values as elements of luxury tourism. A destination's luxury gastronomy (gourmet) products, culture, tradition, history and pristine nature are things that can only be tried and experienced in the destination and the accommodation facility.

In conclusion, based on all analysed attitudes of the respondents, it is possible to create a model for luxury tourism offering development. The model defines the key elements in establishing a luxury tourism offering.

Figure 1: Perception of stakeholders in tourism destination - model for development of luxury tourism offering

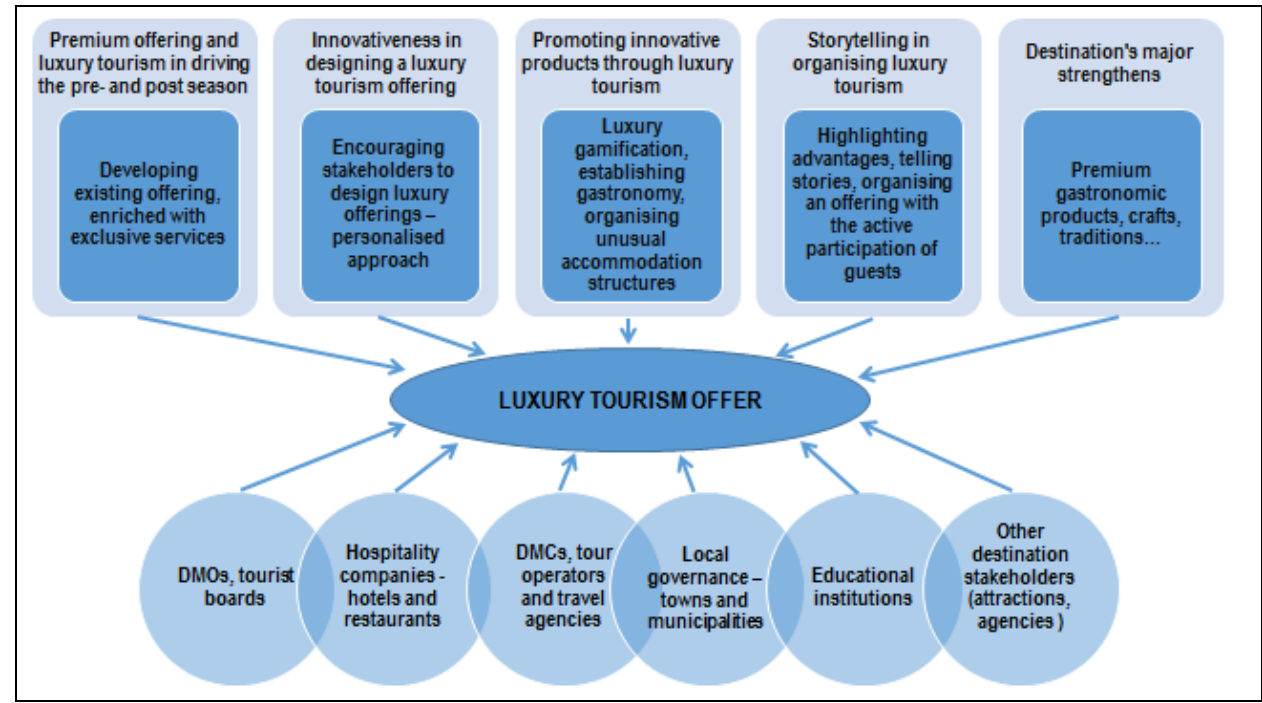

Source: Author's research

The model consists of two basic parts: the innovative elements/activities of a destination's luxury tourism offering and the stakeholders involved in creating the offerings. A platform for the further development of luxury tourism will consist of the right combination of luxury accommodation facilities and additional destination services and offerings, supported by the appropriate marketing activities. In these activities the greatest responsibility is lodged with stakeholders in the destination whose task it is to ensure cooperation and the coordination of activities needed to enable unhindered growth and development. The luxury tourism offering is at the heart of the model, as the intersection of lines connecting the involved stakeholders and the activities aimed at creating the offering. Only by optimising and combining these two elements will it be possible to develop a luxury tourism offering and bolster luxury tourism.

Innovativeness in providing accommodation services is achieved through the implementation of new methods and techniques in organising services and processes. Focused on the luxury experience, a selective mix of services is designed, capable of evoking guests' feelings of satisfaction, pride, self-actualisation and hedonic enjoyment in the comforts of the physical environment. The importance of aligning services, 
ToSEE - Tourism in Southern and Eastern Europe, Vol. 5, pp. 177-189, 2019

M. Cerović, N. Pavia, T. Floričić: THE IMPORTANCE OF INNOVATION IN DESIGNING A

facilities and programmes in the destination with the design and innovation of a luxury accommodation offering is recognised in ensuring a luxury experience throughout the entire stay of guests. In place of typical tourism products, the pull factors for luxury guests are tailor-made accommodation and destination services, with emphasis on experiences and authenticity to enable successful differentiation.

\section{CONCLUSION}

In keeping with upward trends in growing demand for luxury services in tourism, tourism destination stakeholders are aware of the need to design offerings for this category of guests. As a result, some destinations on the market are positioned as luxury destinations, presenting themselves with the quality of their facilities and services rather than with the specific types of facilities and services offered. Luxury guests are oriented towards a personalised, authentic and exclusive offering of novel experiences, the value of which exceeds the pleasure in material goods. Luxury experiences activate the highest levels of meeting human needs - self-actualisation and self-respect, with emphasis on hedonic pleasure and exclusivity (experiences unavailable to the masses). Summarising the findings of previous research and the study conducted for the purpose of this paper leads to the conclusion that luxury tourism is already established on the tourism market despite the academic marginalisation of the phenomenon (due to the perceived value of luxury itself). Preconditions to successfully designing a luxury tourism offering include strategic thinking, stakeholder education and the synchronised development of the accommodation offering and service and facilities in the destination. The potential of this form of the tourism offering is evident in opportunities for revitalising rural, pristine areas and attracting guests with greater purchasing power, thus reducing the scale of mass tourism, lessening marked seasonality and increasing tourist spending.

The value of this study is seen in the obtained results that can be of help to tourism destination stakeholders in designing a luxury tourism offering. The paper is also a contribution to the scant body of scientific literature investigating the concepts of luxury tourism offering design.

\section{ACKNOWLEDGEMENTS}

This paper has been financially supported by the University of Rijeka, for the project ZP UNIRI 9/18. 
ToSEE - Tourism in Southern and Eastern Europe, Vol. 5, pp. 177-189, 2019

M. Cerović, N. Pavia, T. Floričić: THE IMPORTANCE OF INNOVATION IN DESIGNING A ...

\section{REFERENCES}

A Luxury Travel Blog (26/03/2013), Retrieved from 10 Definitions of Luxury Travel from within the Industry: https://www.aluxurytravelblog.com/2013/03/26/so-what-is-luxury-travel/

Bakker, M. (2005), Luxury and tailor-made holidays, travel and tourism analyst, Mintel International Group Ltd., Chicago.

Barcet, A, (2010), "Innovation in services: a new paradigm and innovation model", in Gallouj, F., Djellal, F. (eds.), The Handbook of Innovation and Services: A Multidisciplinary Perspective, Edward Elgar, Cheltenham, pp. 49-67.

Brandão, F. (2014), Innovation in Tourism: the role of regional innovation systems, Thesis for: PhD in Tourism, Universidade de Aveiro, Departamento de Economia, Gestão e Engenharia Industrial, Aveiro, doi: 10.13140/RG.2.1.3719.4409

CBI (2014), What are the opportunities for luxury tourism from Europe? CBI Ministri of Goering Affairs. Retrieved 23 January 2019 from https://www.cbi.eu/node/2597/pdf/

Chan, W.W., To, C.K., Chu, A.W. \& Zhang, a.Z. (2014), "Behavioural Determinants that Drive Luxury Goods Consumption: A Study within the Tourist Context", Research Journal of Textile and Apparel, Vol. 18, No. 2, pp. 84-95 https://doi.org/10.1108/RJTA-18-02-2014-B010

De Brentani, U. (2001), "Innovative versus incremental new business services: Different keys for achieving success", The Journal of Product Innovation Management, Vol. 18, No. 3, pp. 169-187 https://doi.org/10.1111/1540-5885.1830169

Dzhandhhugazova, E., Bilanova, E., Orlova, L. \& M.M., R. (2016), "Innovations in Hospitality Industry", Intenrnational Journal of Environmental \& Science Education, Vol. 11, No. 17, pp. 10387-10400.

Floričić, T. \& Pavia, N. (2018), "Integrated Hotel or Private Accommodation? - Tourist's' responses to Innovative Hospitality", Journal of Spatial and Organzational Dynamics, Vol. 6, No. 3, pp. 271 285.

Gilmore, J. \& Pine, J. (2002), "Differentiating hospitality operations via experiences: why selling services is not enough", The Cornell Hotel and Restaurant Administration Quarterly, Vol. 43, No. 3, pp. 87 96.

Hjalager, A. (2015), "100 Innovations That Transformed Tourism”, Journal of Travel Research:; Foundations of Tourism Research: A Special Series, Vol. 54, No. 1, pp. 3-21.

Maráková, V. \& Medved’ová, M. (2016), "Innovation in tourism destinations", Forum Scientiac Oeconomia Vol. 4, No. 1, pp. 33-43.

Monkhouse, L., Barnes, B. \& Stephan, U. (2012), "The Influence of Face and Group Orientation on the Perception of Luxury Goods: A Four Market Study of East Asian Consumers", International Marketing Review, Vol. 29, No. 6, pp. 647-672 http://dx-doi.org/10.1108/02651331211277982

Mrnjavac, E., Pavia, N. \& Maršanić, R. (2018), "Parking as an Important Service of Innovative Hotels: A Case of Croatia", Innovation Management, Entrepreneurship and Sustainability, Vysoka škola ekonmicka v Praze, pp. 722-733.

Nueno, J. \& Quelch, J. (1998), “The mass marketing of luxury”, Business Horizons, Vol. 41, No. 6, pp. 61-69.

Pavia, N. \& Floričić, T. (2017), "Innovative Accommodation Facilities in Tourism and Hospitality Industry Integrated Hotels", Proceedings of 4th International Scientific conference Tourism in Southern and Eastern Europe: Innovation and Creative Industries: Trends and Challenges, Faculty of Tourism and Hospitality Management, Opatija, pp. 437-450, https://doi.org/10.20867/tosee.04.16

Peters, M. \& Pikkemaat, B. (2006), "Innovation in Tourism", Journal of Quality Assurance in Hospitality \& Tourism, Vol. 6, No. 3-4, pp. 1-6.

Pine, J. \& Gilmore, J. (2014), “A leader's guide to innovation in the experience economy", Strategy Leadership, Vol. 42, No. 1, pp. 24-29, http://doi.org/10.1108/SL-09.2013-0073

Popescu, I. \& Olteanu, V. (2014), "Luxury tourism: Characteristic and trends of the behaviour of purchase", Sea Practical Application of Science, Vol. 2, No. 4., pp. 319-324.

Schumpeter, J. (1934), The Theory of Economic Development, Harvard, MA: Harvard University Press

Simonceska, L. (2012), "The changes and innovation as a factor of competitiveness of the tourist offer (the case of Ohrid)", Procedia - Social and Behavioural Sciences, 44, pp. 32-43, http://doi:10.1016/j.sbspro.2012.05.002

Smits, R. (2002), "Innovation studies in the 21st century: Questions from a user's perspective", Technological Forecasting and Social Change, Vol. 69, No. 9, pp. 861-883, http://doi:10.1016/S0040-1625(1)00181-0

Stankova, M. \& Kaleichev, S. (2013), “The Cutting Edge Between The Mass and Luxury Tourism”, Romanian Economic and Business Review (Special Issue), pp. 50-59. 
ToSEE - Tourism in Southern and Eastern Europe, Vol. 5, pp. 177-189, 2019

M. Cerović, N. Pavia, T. Floričić: THE IMPORTANCE OF INNOVATION IN DESIGNING A ...

Tounta, P. (2015), Building the future of tourism through innovation, viewed $19^{\text {th }}$ December 2018 https://insights.ehotelier.com/insights/2015/04/20/building-the-future-of-tourism-throughinnovation/

Tynan, C., McKechnie, S. \& Chhuon, C. (2010), "Co-creating value for luxury brands", Journal of Business Research, Vol. 63, No. 11, pp. 1156-1163.

UNWTO (2016), Report of the Committee on Tourism and Competitiveness CE/103/5 rev.2. Retrieved from Sustainable Development of Tourism: Conceptual Framework: http://cf.cdn.unwto.org/sites/all/files/docpdf/generalprogrammeofworkdmgt.pdf

Vigneron, F. \& Johnson, L. (2004), "Measuring perceptions of brand luxury", Journal of Brand Management, Vol. 11, No. 6, pp. 484-506.

Wiedmann, K., Hennigs, N. \& Siebels, A. (2009), "Value-based segmentation of luxury consumption behaviour", Psychology and Marketing, Vol. 26, No. 7, pp. 625-651. https://doi.org/10.1002/mar.20292

WTF (19/01/2019), World Tourism Forum, Retrieved Luxury Tourism: Concept and Trends: http://blog.worldtourismforum.net/luxury-tourism-concept-and-trends/

Yang, W. \& Mattila, A. (2016), "Why do we buy luxury experiences? Measuring value perceptions of luxury hospitality services”, International Journal of Contemporary Hospitality Management, Vol. 28, No. 9, pp. 1848-1867, https://doi.org/10.1108/IJCHM-11-2014-0579

Marta Cerović, PhD, Assistant

University of Rijeka

Faculty of Tourism and Hospitality Management

Ika 42, 5140 Opatija, Croatia

Phone: +385-51-294190

E-mail:martau@fthm.hr

Nadia Pavia, $\mathrm{PhD}$, Full Professor

University of Rijeka

Faculty of Tourism and Hospitality Management

Ika 42, 5140 Opatija, Croatia

Phone: +385-51-294190

E-mail: nadiap@fthm.hr

Tamara Floričić, $\mathrm{PhD}$, Assistant Professor

Juraj Dobrila University of Pula

Faculty of Economics and Tourism "Dr. Mijo Mirković"

Preradovićeva 1/1, 52000 Pula, Croatia

Phone: +385-52-377029

E-mail: tfloricic@unipu.hr 